biora udział kadeci z krakowskiej szkoły, różnorakie akcje ratownicze oraz wykorzystanie zdolności i umiejętności słuchaczy dla podniesienia wyposażenia placówki.

Piaty rozdział zawiera wypowiedzi byłych komendantów szkoły, którzy zwracają uwagę na wyposażenie placówki w najnowocześniejszy sprzęt i pomoce naukowe oraz na to, ze praca krakowskiej PSP to nie tylko codzienne planowe zajęcia, ale także szereg dodatkowych dzialaí na rzecz środowiska.

Walory dydaktyczne i estetyczne książki podnosza zamieszczone na końcu fotografie komendantów szkoły oraz fotografie ilustrujące różne uroczystości i życie codzienne kadetów. Napisana jest w sposób komunikatywny. Interesujące jest wieloaspek towe, wydaje się, całościowe potraktowanie działalności placówki.

Przedstawiona publikacja może być interesująca nie tylko dla ludzi związanych $z$ kształceniem przeciwpożarowym, ale również dla osób kierujących innymi placówkami oświatowymi jako przykład kształcenia i wychowania powiazanego z praktykq, życiem codziennym oraz pełnego wykorzystania możliwości pracowników, uczniów i środowiska.

Miroslawa Walczak

\title{
Bibliografia historii wychowania (druki zwarte wydane w Polsce w l. 1994-1995)
}

Akademia Zamojska $i$ jej tradycje. Referaty przygotowane na sesje naukowq zorganizowang dla upamiętnienia 400 rocznicy utworzenia przez Jana Zamoyskiego Akademii Zamojskiej, 27-28 maja 1994 w Zamościu, red. Szyszka B., Zamość 1994, ss. 147;

Akademia Zamojska: bibliografia, oprac. Markiewicz G., Pałczyńska R., Zamość 1994, ss. 37;

Album studentów Akademii Zamojskiej 1595 1781, oprac. Gmiterek H., Warszawa 1994, ss. 604 ;

Ariès $\mathbf{P}$, Historia dziecinstwa. Dziecko i rodzina w dawnych czasach, przek. Ochab M., Gdańsk 1995 , ss. 239;

August Cieszkowski, Welkopolanin i Europej$c z y k$, pod red. Goryńskiej-Bittner B. i Stępnia J., Poznań 1994, ss. 185;

Balicki M., Szkolnictwo bialostockie w latach 1944 - 1972. Studium historyczno-porównawcze, Białystok 1995, ss. 222;

Baran A. F, Z dziejów harcerstwa tarnobrzeskiego 1912 -1949. Tarnobrzeg 1995, ss. 99;

Barnes J., Arystoteles, Warszawa 1995, ss. 104;
Brūblmeier A, Edukacja humanistyczna, Kraków 1994, ss. 239;

Budzewicz Z., Ksztalcenie literackie w szkolach zawodowych w l. 1918-1939, Kraków 1994, ss. 146;

Chachaj M., Zagraniczna edukacja Radziwillów. Od poczqtku XV do polowy XVI wieku, Lublin 1995, ss. 171;

Darowski R., Filozofia w szkolach jezuickich w polsce w XИ wieku, Kraków 1994, ss. 447;

Dzieje Liceum Ogólnoksztalcqcego w Sulejówlu: 1944 - 1994, praca zbiorowa pod red. Kolodziejczyka A., Sulejówek 1994, ss. 186;

Gawlik S, Dziedzictwo pedagogiczne Klementyny z Taniskich Hoffmanowej. Opole 1995, ss. 117 ;

Gromadzka E., Z historii Szkoly Rolniczej w Eowiczu-Blichu. 1925-1995, Lowicz 1995, ss. 46;

Grześ B, Deportacja nauczycieli do ZSRR 1939 - 1941, Warszawa 1995, ss. 158;

Grzywna J., Guldon Z., Możdżeń S., Podstawy warsztatu historyka oswiaty, Przewodnik metodyczny do prac magisterskich, Kielce 1994; 
Hellwig J., Jamrożek W, Żoł̨dż D., Z prac poznaniskich historyków wychowania, Poznań 1994, ss. 142;

Hellwig J., Prolegomena do historii wychowania, Poznań 1995, ss. 124;

Hellwig J., Rola Towarzystwa Naukowej Pomocy im. Karola Marcinkowskiego w awansie spoleczno-zawodowym mlodzieży polskiej, Poznań 1994 , ss. 120 ;

Historia wychowania, Skrypt dla studentów studiów dziennych $i$ zaocznych, red. Hellwig J., Poznań 1994, ss. 146;

Historia wychowania. Slownik biograficzny, Olsztyn 1994 , ss. 142 ;

Il Ogolnopolski Zjazd Pedagogiczny. Demokracja a wychowanie, Materiały przedzjazdowe, Toruń 1995, ss. 234;

Jakubiak $\mathrm{K}$, Wychowanie państwowe jako ideologia wychowawcza sanacji. Ksztaltowanie i upowszechnianie w periodycznych wydawnictwach spoleczno-kulturalnych $i$ pedagogicznych, Bydgoszcz 1994, ss. 226;

Jamrożek W, Idee edukacyjne polskiej socjalnej demokracji w Galicji do 1918 roku, Poznań 1994, ss. 204;

Jaworski A., Dzieje szkolnictwa górniczego wegla kamiennego w Polsce do roku 1992. Opole 1994, ss. 300;

Jaxa-Kwiatkowska B, Profesor Ludwik JaxaBykowski (1881-1948), Ostatnie lata życia, Warszawa 1994, ss. 120;

Karolewicz G., Nauczyciele akademiccy Katolickiego Uniwersytetu Lubelskiego w okresie miedzywojennym, Lublin 1994, ss. 322;

Katolicki Uniwersytet Lubelski, 75 lat w shużbie Bogu i Ojczyźnie, Album jubileuszowej wystawy, oprac. Szymik J., Lublin 1994, ss. 110;

Katolicki Uniwersytet Lubelski, Ksiega pamiqtkowa w 75-lecie Katolickiego Uniwersytetu Lubelskiego, Lublin 1994, ss. 828;

Kazanowski K., Martyrologia nauczycieli w lubelskim w latach II wojny swiatowej, Lublin 1995, ss. 89;
Kosiek A., Z dziejów starań miasta Krosna o zalożenie gimnazjum i szkoly realnej, Krosno 1994, ss. 36;

Kotarski S, Polityka mocarstw zachodnich wobec szkolnictwa wyższego Niemiec 1945-1949, Gdańsk 1994, ss. 173;

Koźmian D., Poglady spoleczno-pedagogiczne Aleksandra Kazimierza Patkowskiego (1890. 1942), Szczecin 1994, ss. 144;

Krąpiec M. A, Poznawad czy mysleć: problemy epistemologii tomistycznej, Lublin 1994, ss. 326;

Kupisiewicz C, Koncepcje reform szkolnych w latach osiemdziesiqtych, Warszawa 1994, ss. 152;

Lewandowska-Kozimala I., Skauting polski w Galicji Wschodniej, Przemyśl 1994, ss. 139;

Marek Z., Rozwoj teorii religijnego wychowania dziecka w wieku przedszkolnym w Polsce w latach 1945 -1990, Kraków 1994, ss. 351;

Metoda Marii Montessori. Historia i wspólczesnosć, red. Guz S., Lublin 1994, ss. 155;

Michalik B., Bibliografia dziejów oświaty polskiej w okresie II wojny swiatowej, $\mathrm{Cz} .3$, Warszawa 1994, ss. 147;

Michalska I., Michalski G., Wychowanie przez teatr szkolny w II Rzeczypospolitej, Warszawa 1994, ss. 126;

Michalska I., Czasopisma Zwiqzku Nauczycielstwa Polskiego dla dzieci w okresie Drugiej Rzeczypospolitej, Lódź 1994, ss. 193;

Michalski G., Zygmunt Myslakowski (18901971). dzialalnośc $i$ twórczość pedagogiczna, Lódź 1994, s. 152;

Michalski S., Praca naukowo-badawcza nauczycieli w Drugiej Rzeczypospolitej, Poznań 1994, ss. 190 ;

Mróz M. W., Dzialalnośc dydaktyczna Wyższej Szkoly Handlowej - Szkoly Glównej Handlowej w latach 1915-1939, Warszawa 1994, ss. 238;

Nauka i oświata, red. Meissner A. i Wyrozumski J. (w: Galicja $i$ jej dziedzictwo, t. III), Rzeszów 1995, ss. 286; 
Nauki pedagogiczne w Polsce. Tradycje-wspólczesność-przyszlosć, red. Michalski S., Ossowski R., Bydgoszcz 1994, ss. 561;

Od wieków ksztalci pasterzy, Wyższe Seminarium Duchowne we Woclawku, zespół red. Bagrowicz J. i in, Włoclawek 1994, ss. 115;

Organizacja i funkcjonowanie wspólczesnych systemów edukacyjnych, wyb. i oprac. Gumula T, Krasuski J., Majewski S., Kielce 1994, cz I - ss. 275 , cz. II - ss. 252 , cz. III - ss. 160 ;

Palacz R., Sokrates, Zielona Góra 1994, ss. 226;

Pauli H. Szkolnictwo rolnicze w Boleslawowie w latach 1945-1995, ИI Jubileuszowy Zjazd Absolwentów, Bolesławowo 1995, ss. 125 ;

Perkowska U, Studentki Uniwersytetu Jagiellońskiego w latach 1894 - 1939. W stulecie immatrykulacji pierwszych studentek, Kraków 1994, ss. 266 ;

Pitala A., Kolegium Pijarów w Krakowie, Kraków 1994, ss. 274;

"Podkowiacy", Wychowankowie Państwowego Gimnazjum im. Stefana Batorego w Warszawie, oprac. Leśniewski A. i Kujawski E., Warszawa 1994, ss. 261;

Polacy $i$ Niemcy. Plaszczyzny i drogi normalizacji. duszpasterstwo $i$ szkolnictwo. Materiały z sympozjum naukowego odbytego w Opolu w dniach 14 - 16 pażdziernika 1993 roku, red. Lis M., Opole 1994, ss. 142;

Polityka a wychowanie. Szkice z dziejów wychowania spolecznego w Polsce, pod red. Wojtasa A., Torun 1994, ss. 111;

Popławski Z., Wykaz pracowników naukowych Politechniki Lwowskiej w latach 1844-1945. Kraków 1994, ss. 221;

Potempa E. A., 70 lat Gimnazjum i Liceum im. Króla Jana III Sobieskiego w Piekarach Ślqskich, Piekary Sląskie 1994, ss. 167;

Potoczny J., Od alfabetyzacji do popularyzacji wiedzy. Ruch oświaty dorosłych w Galicji (1867-1918), Rzeszów 1994, s. 120;

Przybylski T., $Z$ dziejów nauczania muzyki w Krakowie. Od średniowiecza do czasów wspótczesnych, Kraków 1994, ss. 377;
Purczyński W., Seminarium Nauczycielskie i Liceum Pedagogiczne w Wagrowcu w latach 1920 1969. Wągrowiec 1994, ss. 194;

Ravier A., Ignacy Loyola zaklada Towarzystwo Jezusowe. Warszawa 1994, ss. 493;

Richè P., Edukacja i kultura w Europie Zachodniej ( И-VII w.), Warszawa 1995, ss. 557;

Rodzina a wychowanie - cigglośc i zmiennosć na przestrzeni wieków, red. Jundzitł J., Bydgoszcz 1995 , ss. 144;

Rodzina jako srodowisko wychowawcze w czasach nowożytnych, red. Jakubiak K., Bydgoszcz 1995 , ss. 304;

Rodzina jako środowisko wychowawcze w czasach nowożytnych - koncepcje teoretyczne i praktyka. Tezy i streszczenia referatów, Bydgoszcz ss. 126;

Rodzina w spoleczeństwach antycznych $i$ wczesnym chrześcijanistwie. Literatura, prawo, epigrafika, sztuka, red. Jundziłł J, Bydgoszcz 1995, ss. 346;

Rozwój ksztalcenia zawodowego $i$ oświaty doroslych, pod red. Wujka T, Warszawa 1994, ss. 173;

Rynio A., Wychowanie mlodzieży w nauczaniu Kardynala Stefana Wyszyńskiego, Lublin 1995, ss. 338;

Rys J, Szkolnictwo parafialne w miastach Malopolski w XV wieku, Warszawa 1995, ss. 150;

Skowronek J., Mlodzież polska i jej organizacje w ruchu narodowym 1795-1864, Warszawa 1994, ss. 88;

Slownik biograficzny katolicyzmu spolecznego, Lublin 1994, t. 1 (A-J) - ss. 201, t. 2 (K-P) - s. 218 ;

Snoch $\mathrm{B}_{\neg}$ Historia wychowania. Przewodnik dla studentów zaocznych. Warszawa 1994, ss. 32;

Socha J., Dzialalnosć Centralnego Towarzystwa Rolniczego w dziedzinie oswiaty rolniczej 1907 1929. Lódź 1994, ss. 148;

Stan $i$ perspektywy historii wychowania, red. Jamrożek W., Poznań 1995, ss. 157;

Stasiukiewicz-Jasiukowa I., Encyklopedia uniwersalna Księcia Biskupa Warmińskiego i jej 
rola w edukacji obywatelskiej czasów stanislawowskich, Warszawa 1994, ss. 238;

Stopinska-Pajak A., Andragogika w Drugiej Rzeczypospolitej. Warunki rozwoju, problematyka, koncepcje, Katowice 1994, ss. 219;

Studia z dziejów edukacji, wybór Miąso J., Warszawa 1994, ss. 356;

Szkola Rolnicza w Czernichowie im. Franciszka Stefczyka. Zarys historii (1860-1995), Czernichów 1995, ss. 70;

Sztobryn S., Filozofia wychowania Sergiusza Hessena, Lódź 1994, ss. 223;
Szulakiewicz W., Madyslaw Seredyński, Studium $z$ dziejów pedagogiki galicyjskiej (w: Galicja $i$ jej dziedzictwo, t. VI), Rzeszów 1995, ss. 166

Teksty źrodlowe do dziejow wychowania, wyb. i oprac. S. I. Możdżeń, cz. 6: Wek XIX $i$ poczqtek XX, Kielce 1994, ss. 155;

Z dziejów szkolnictwa jezuickiego w Polsce, Kraków 1994, ss. 260.

Wilno jako ognisko oświaty w latach próby (1939-1945). Swiadectwa czasu, oprac. Feliksiak E., Skorko-Barańska M., Białystok 1994, ss. 544 ; 